\title{
Rebellion and Mutiny in the Mariana Islands, $1680-1690^{*}$
}

Abstract: The fledgling Spanish colony in the Marianas was rocked by seven episodes of mutiny in the 1680 s, culminating in the successful takeover of the island of Guam in 1688 by a group of mutineers led by a convict captain. In the context of ongoing campaigns of indigenous resistance to Spanish colonisation, the actions of these mutinous soldiers placed the project of empire building in the Marianas in serious peril. The events surrounding these mutinies have often been underplayed within a historiography that focuses on the violent nature of the Spanish presence in the Marianas. Nevertheless, the soldiers' mutinies of the 1680 s add another perspective to this turbulent history. The experience of mutiny raises considerable questions about the nature of loyalty amongst the ordinary soldiers to the project of empire building the Pacific. It demonstrates that Spanish soldiers and often their Filipino counterparts - had the capacity to destabilise the imperial project from within.

At seven in the morning on 12 September 1690, nine mutineers were lined up on the beach at Hagatna, Guam, with their backs to coconut trees, and shot with arquebuses. These soldiers had arrived by chance in the Mariana Islands four months earlier when their ship had been wrecked on a reef close to the island of Guam. All of them were convicts sent from Mexico to serve a sentence of forced military conscription in the Philippines. Accused of conspiring with the intention to kill the royal and religious officials on Guam and to seize a ship and sail for Peru, they joined fourteen of their comrades whose blood stained the sands of Hagatna's beach over three days that September. These twenty-three deaths violently brought to a close a decade of mutiny in the tiny Spanish outpost in the Pacific. In recounting the events to their superiors in Madrid and Rome, the Jesuit friars attending to the souls of these mutineers noted that, as the last one fell, there was a sudden change of wind, marking the end of the monsoon and the beginning of the prosperous trade winds that would carry the supply ships to the islands from Manila. This change of wind was followed by a celebration within the Spanish missionary population that marked the end of an era of sedition. ${ }^{1}$

The history of the early Spanish settlement of the Mariana Islands is widely understood as a turbulent time of turmoil and resistance to Spanish colonisation by the indigenous Chamorro inhabitants of the islands, which began almost immediately after the arrival of Jesuit missionaries in 1668. Several decades of resistance and brutal pacification ensued before the islands were finally

\footnotetext{
* Acknowledgments: This paper has benefited from the helpful comments of A/Prof. Michael McDonnell, Dr. Sujit Sivasundaram, Dr. John Gagné, and Karol Florek, as well as the thoughtful feedback of the reviewers and editors at the Journal of Pacific History. The research undertaken in the Micronesian Area Research Center was generously supported by the Paul Bourke Postgraduate Travel Fellowship from the Australia and New Zealand American Studies Association, and also made possible by the helpful guidance around MARC by Dr. Omaira Brunal-Perry.

${ }^{1}$ Micronesian Area Research Center (MARC hereinafter), Real Academia de la Historia (RAH hereinafter), Cortes 567, Legajo 12: 'Estado de las Marianas en la Milicia por Diego de Zarzossa y Lorenzo Bustillo, S.J.' Archivo General de Indias (AGI hereinafter), Ultramar, Legajo 562.
} 
brought under nominal Spanish control in 1696. Within this history of rebellion and resistance, the role of ordinary soldiers has often been reduced to one of mere conquistador - the brutal and unthinking agents of empire in the Spanish Pacific. This article proposes to re-examine the early colonial history of the Marianas from the perspective of these agents of empire. I focus in particular on the decade 1680-1690 during which five separate moments of mutiny took place amongst the soldiers stationed in Guam. Despite taking place in the midst of ongoing indigenous resistance to Spanish colonisation, these mutinies have largely been ignored or downplayed in the existing historiography. Where the soldiers' mutinies have been mentioned in accounts of the early colony in Guam, they have usually been tacked on as a post-script to the narrative of the indigenous uprising, ${ }^{2}$ or placed within a longer narrative of political corruption amongst the islands governors. ${ }^{3}$

The soldiers' mutinies within the Guam garrison during the 1680 s are nonetheless extraordinary examples of how ordinary soldiers could influence the course of imperial expansion in the early modern Pacific. As was the case elsewhere in the Spanish Pacific, the soldiers who served in the Marianas were a rag-tag mix of indigenous Filipinos, Mexican mestizos and Spanish convicts, many of whom served in some degree of unfreedom. The experience of mutiny raises considerable questions about the nature of loyalty amongst these ordinary soldiers to the project of empire building in the Pacific. It demonstrates that Spanish soldiers - and often their Filipino counterparts had the capacity to destabilise the imperial project from within.

During the seventeenth century, Spanish power in the Pacific was concentrated within the Philippine islands of Luzon and the Visayas, which were administratively controlled by and reliant on the viceroyalty of New Spain, in present-day Mexico. The Spanish crown utilised this base to engage in projects of domination and wars of attempted conquest across South East Asia and the Pacific, in Muslim controlled Mindanao and the Sulu Sea, the spice islands of Ternate and Tidore in the Moluccas, the Marianas, and in Taiwan. The establishment of the Marianas mission in 1668 was also the catalyst for a new era of exploration and discovery of many smaller islands throughout the Pacific, including the Caroline Islands and the Austral Islands, which the-some Spanish believed

\footnotetext{
${ }^{2}$ Alexandre Coello de la Rosa, 'Colonialismo y santidad en las islas Marianas: Los soldados de Gedeón (16761690),' Revista Española de Historia, 70: 234 (2010), 36-37.

3 Marjorie G. Driver, 'Cross, Sword and Silver: The nascent Spanish colony in the Mariana Islands,' Pacific Studies, 11:3 (1988), 21-51. Francis X. Hezel, and Marjorie G. Driver, 'From Conquest to Colonisation: Spain in the Mariana Islands, 1690-1740,' The Journal of Pacific History, 23: 2 (1988), 142-143. Augusto V. De Viana, In the Far Islands: The Role of Natives from the Philippines in the Conquest, Colonization and Repopulation of the Mariana Islands, 1668-1903, (Manila: University of Santo Tomas Publishing House, 2004), 110.
} 
would bring them closer to discovering the rumoured Terra Australis..$^{||}$Soldiers were present throughout all of these projects of exploration and conquest. Yet, our understanding of who these soldiers were and what motivated them is rudimentary. Historians of the Philippines have often assumed that soldiers' interests were intertwined with those of their King and their military commanders, drawing on the infamous and often stereotyped image of the Spanish conquistadors who conquered the territories of New Spain and Peru and were richly rewarded with land and treasure for their efforts. ${ }^{5}$ This image has never been adequately interrogated within Philippine historiography. Even the relatively well-studied history of the early colony on Guam exhibits this same bias, with historians emphasising the conflict between ordinary soldiers and ChamorrosChamorro-Chamorro without analysing the conditions of exploitation and discontent experienced by these same soldiers. Many accounts either pass over or simply fail to mention the series of mutinies that coincided with indigenous resistance. ${ }^{6}$ By contrast, the following discussion argues that soldiers' loyalty to the colonial project could not be presumed, despite the fact that the loyalty of soldiers was vital for the success of Spanish expansion.

Although the events in Guam in the 1680s are somewhat extraordinary for their extent and scale, they reflect a broader experience of rebelliousness amongst soldiers stationed across the Spanish Pacific. The majority of soldiers serving in the Pacific were recruited in New Spain; however viceregal authorities in New Spain consistently struggled to find sufficient volunteers willing to make the Pacific crossing and consequently relied heavily on both formal and informal methods of coerced recruitment to fill the needed quotas. ${ }^{7}$ Thus, from the very outset loyalty amongst Spanish soldiers in the Philippines was problematic, since so many found themselves transported across the Pacific against their will. The conditions experienced within Spain's Pacific presidios ${ }^{8}$ were also catalysts for disaffection. Spanish soldiers were subject to exploitation, deprivation, disease and endemic danger from being surrounded by hostile neighbours both internally and externally to the archipelago.
Comment [B1]: the Spanish drive to find la parte Austral incognita stemmed largely from Peru and the personal obsessions of Mendaña and Quirós

Comment [S2]: The voyages in search of Australia undertaken from Peru took place a century earlier than the period under consideration in this article - as is the case with the contents of Spate's book. Attempted colonisation of the Caroline Islands did not take place until the eighteenth century. I remember reading in Levesque's History of Micronesia that some of the Jesuits utilised the promise of

finding Terra Australis as a justification for their continued presence in the Mariana Islands - which was also part of the impetus to 'discover' the Carolines and

Austral Islands. Unfortunately, I am away this month in St. Louis and do not have access to Levesque's books, so I cannot look up this reference, but could do so once back in Cambridge.

I have now included a reference to Spate.

Comment [B3]: Spate is a glaring omission from this footnote and indeed from the references as a whole

Comment [B4]: the plural ' $s$ ' is not usually used with indigenous Pacific names

\footnotetext{
${ }^{4}$ Matt K. Matsuda, Pacific Worlds: A History of Seas, Peoples, and Cultures, (Cambridge: Cambridge University Press, 2012), 118. Deryck Scarr, The History of the Pacific Islands: Kingdoms of the Reefs, (Melbourne: The Macmillan Company of Australia Pty Ltd., 1990), 94-105. Robert F. Rogers, Destiny's Landfall: A History of Guam, (Honolulu: University of Hawai'i Press, 1995), 70. O.H.K. Spate, The Spanish Lake, (Canberra: ANU EPress, 2004), 119-143.

${ }^{5}$ Robert R. Reed, Colonial Manila: The Context of Hispanic Urbanism and Process of Morphogenesis, (Berkeley: University of California Press, 1978), 11-14. John Leddy Phelan, The Hispanization of the Philippines: Spanish Aims and Filipino Responses, 1565-1700, (Madison: The University of Wisconsin Press, 1967). Renato Constantino, The Philippines: A Past Revisited, (Quezon City: Tala Publishing Services, 1975), 41. Scarr, The History of the Pacific Islands, 82-105.

${ }^{6}$ Rogers, Destiny's Landfall, 58-73.

${ }^{7}$ Stephanie Mawson, 'Unruly Plebeians and the Forzado System: Convict Transportation between New Spain and the Philippines during the Seventeenth Century,' Revista de Indias, 73:259 (2013), 693-730.

${ }^{8}$ A presidio is a fortification with a garrison of soldiers. In this period, there was no established association with a penal institution, although most presidios employed convict labourers.
} 
Moreover, soldiers were rarely ever paid and many found themselves serving in presidios where the hope of rotation or relief from duty was non-existent. Thus, soldiers rebelled against conditions of isolation and deprivation common to Pacific presidios. While many chose the individual act of desertion, mutiny became a collective response to the expectation that they would simply, in the words of the Philippine Governor Manrique de Lara, 'resign themselves to death from a life of fatigue without resources. ${ }^{9}$

Charting the presence of mutiny in the Spanish Pacific is nonetheless not an easy undertaking and the full extent of mutiny among Spanish soldiers stationed in the Pacific in the seventeenth century is as yet unknown. Moreover, with some notable exceptions, the details surrounding soldiers' mutinies are patchy. We do not have, for instance, criminal records that might give us an insight into the motivations of those engaging in mutiny. Most known instances of mutiny took place in remote presidios where due process was not followed and legal records were not kept. In some cases, soldiers were summarily executed before word of the mutiny could be reported to royal officials in Manila, let alone to the Council of Indies in Madrid. Mostly, mutinies are mentioned only in passing and without detail, buried within letters or other administrative records. The exceptions to all of this are the mutinies that took place in the Mariana Islands between 1684 and 1690 . Detailed letters kept by the Jesuit missionaries make it possible for the researcher to piece together the events surrounding these mutinies in great detail. These events thus make an interesting case study for historians not only of Micronesia but also of the broader Spanish presence in the seventeenth century Pacific.

By focussing on the contested nature of loyalty among Spanish soldiers, this article emphasises the dynamic and fluid nature of colonial interactions on the frontier, bringing to life hidden narratives of contestation and negotiation between colonisers and colonial subjects. For some time now, historians of the Americas have noted the exceptional nature of colonial frontiers as sites of contestation, conflict and interaction. ${ }^{10}$ Guy and Sheridan define the frontier regions of North and South America as 'contested ground,' as zones where imperial power was tenuous. They see

\footnotetext{
${ }^{9}$ AGI, Audiencia de Filipinas (Filipinas hereinafter), Leg. 23, Ramo 2, Núm. 4. AGI, Filipinas, Leg. 9, Ramo 2 , Núm. 34. AGI, Filipinas, Leg. 9, Ramo 2, Núm. 30.

${ }^{10}$ Donna J. Guy, and Thomas E. Sheridan (eds.), Contested Ground: Comparative Frontiers on the Northern and Southern Edges of the Spanish Empire, (Tucson: University of Arizona Press, 1998). Amy Turner Bushnell and Jack P. Greene, 'Peripheries, Centers, and the Construction of Early Modern American Empires,' in Christine Daniels and Michael V. Kennedy (eds.), Negotiated Empires: Centers and Peripheries in the Americas, 15001820, (New York: Routledge, 2002), 1-14. Caroline A. Williams, 'Opening New Frontiers in Colonial Spanish American History: New Perspectives on Indigenous-Spanish Interactions on the Margins of Empire,' History Compass, 6:4, (2008), 1121-1139. Fabricio Prado, 'The Fringes of Empires: Recent Scholarship on Colonial Frontiers and Borderlands in Latin America,' History Compass, 10:4, (2012), 318-333.
} 
frontiers as areas of both volatility and vitality, prone to violence and confrontation but also as sites of negotiation where imperial cultures could be both resisted and adapted. ${ }^{11}$ Similar conclusions can be made about the distant frontier of the Spanish Pacific. On the frontiers, the process of consolidating Spanish control was subject to resistance, violence and warfare - themes that are downplayed in a literature that seeks to examine the progressive dominance of Spanish imperialism against a backdrop of indigenous passivity. ${ }^{12}$ Thus by studying the narrative of events on the colonial frontier of the Spanish Pacific, we challenge the inherent assumption of a quiet and complicit progression towards imperial domination. Ultimately, this article concludes that at particular moments, there were many more similarities in experience that united Spanish soldiers with indigenous communities than has previously been acknowledged, giving us a glimpse into new identities and solidarities that could emerge at moments of disruption and struggle.

This study draws predominantly on archival material contained within the Micronesian Area Research Center in Guam and the Archivo General de Indias in Spain. The types of sources under consideration include letters and reports written by the Jesuit missionaries, correspondence between the governors of the Marianas and the Philippines, the viceroy of New Spain and the King of Spain, criminal records, royal decrees, ships' records and other administrative documents. An analysis of these archival materials allows for a fresh examination of the role that ordinary soldiers played in the project of conquest and colonisation in the Mariana Islands. The article begins with a brief overview of the history of the Spanish presence in the Mariana Islands prior to the 1680s, focussing on how the scale of indigenous resistance forced the Jesuit mission to shift from being a largely peaceful undertaking to relying on military protection for its survival. The remaining two sections focus on the specific case study of mutiny in Guam between 1684 and 1688, seeking in particular to examine the origins and motivations of the rebellions that took place. These mutinies represent moments when the Spanish imperial project in the Pacific was effectively disrupted, demonstrating that resistance to empire was not exclusive to indigenous peoples.

\section{Spanish Soldiers in the Colonisation of the Mariana Islands}

First charted by Magellan in 1521, the Mariana Islands had a long history of contact with the Spanish after 1565 . As the first group of islands encountered during the lengthy voyage across the Pacific,

\footnotetext{
${ }^{11}$ Guy and Sheridan, Contested Ground, 11-15.

${ }^{12}$ Amy Turner Bushnell, 'Gates, Patterns, and Peripheries: The Field of Frontier Latin America,' in Christine Daniels and Michael V. Kennedy (eds.), Negotiated Empires: Centers and Peripheries in the Americas, 15001820, (New York: Routledge, 2002), 23-24.
} 
the Marianas were a regular stopover point for the Spanish galleons bound for Manila throughout the seventeenth century. They provided an opportunity for the Spanish to take on fresh water while trading iron goods such as nails with the indigenous Chamorros Chamorro in exchange for supplies. ${ }^{13}$ Iron was such a valuable commodity within the Marianas that each year Chamorroschamorro would sail out in hundreds of canoes to greet the arrival of the galleons and eagerly engage in trade. ${ }^{14}$ Throughout these encounters, the Chamorroschamorro were seen as peaceful and receptive towards their Spanish guests. The experiences of survivors who washed ashore in the islands after two notorious shipwrecks in 1601 and 1638 were somewhat more mixed. On both occasions some of the survivors were killed by the Chamorroschamorro, yet many others were accepted into the community and some remained there permanently. ${ }^{15}$ Survivors of the 1638 wreck of the Concepción were found to still be living on Guam and Rota when the Jesuits arrived in 1668, and at least one of these survivors was instrumental in acting as a translator for the missionaries. ${ }^{16}$

The perceived amiability and receptiveness of the Chamorroschamorro to Spanish people was a clear factor behind the Jesuit plan to establish a mission in the archipelago in 1668. The original plan conceived of the Spanish colony in the Marianas as a project of settlement rather than military occupation. ${ }^{17}$ While the mission was supported militarily, the soldiers that accompanied the Jesuits were initially thought of mostly as settlers. ${ }^{18}$ The majority of soldiers that accompanied the Jesuit priest Fray Sanvitores in 1668 were Filipinos, who were sent with the intention of providing an example of Christian living to the Chamorros Chamorro, while also educating them in matters of farming and weaving. ${ }^{19}$ Other Filipinos were also employed within the missionary work as

\footnotetext{
${ }^{13}$ Rogers, Destiny's Landfall, 10-20. Marjorie G. Driver, 'An account of the islands of the Ladrones,' The Journal of Pacific History, 26:1 (1991), 103-106. Omaira Brunal-Perry, 'Las islas Marianas enclave estratégico en el comercio entre México y Filipinas,' in Leoncio Cabrero (ed.), España y el Pacífico: Legazpi, Tomo I, (Madrid: Sociedad Estatal de Conmemoraciones Culturales, 2004), 545-547.

${ }^{14}$ Frank Quimby, 'The Hierro Commerce: Culture Contact, Appropriation and Colonial Entanglement in the Marianas, 1521-1668,' The Journal of Pacific History, 46:1 (2011), 1-26.

${ }^{15}$ AGI, Filipinas, Leg. 19, Ramo 2, Núm. 15. William Lytle Schurz, The Manila Galleon: The Romantic History of the Spanish Galleons Trading Between Manila and Acapulco, (New York: E.P. Dutton \& Co., Inc., 1959), 255-

259. Jesús Martínez Pérez, Fray Juan Pobre de Zamora: Historia de la Pérdida y Descubrimiento del Galeón "San Felipe”, (Ávila: Institución "Gran Duque de Alba" de la Excma. Diputación Provincial de Ávila, 1997). Marjorie G. Driver, Fray Juan Pobre in the Marianas, 1602, MARC Miscellaneous Series No. 8, (Guam: Micronesia Area Research Centre, 2004). 'Events in the Philipinas from the year 1638 to that of 1639,' in Emma Helen Blair and James Alexander Robertson (eds.) The Philippine Islands, 1493-1803: explorations by early navigators... (B\&R hereinafter), Vol. 29, (Cleveland, Ohio: A. H. Clark, 1903-9), 168-172. Richard J. Shell, 'The Ladrones Population,' Journal of Pacific History, 36:2 (2001), 225-236.

16 'Events in the Philipinas from the year 1638 to that of 1639, ' $B \& R$, Vol. 29, pp. 168-172.

${ }^{17}$ Alexandre Coello de la Rosa, 'Colonialismo y santidad en las islas marianas: la sangre de los mártires (16681676),' Hispania Sacra, 53:128, (2011), 716.

${ }^{18}$ AGI, Ultramar, Leg. 562.

${ }^{19}$ Augusto V. De Viana, 'The Pampangos in the Mariana Mission, 1668-1684,' Micronesian Journal of the Humanities and Social Sciences, 4:1 (2005), 1.
} 
catechists. ${ }^{20}$ As the mission became more established, a significant number of soldiers - both Spanish and Filipino - took Chamorro women as their wives and were accepted into the colony by the Jesuits as permanent settlers. ${ }^{21}$ In this manner, soldiers married to local wives were entrusted with the responsibility of establishing a viable Spanish community within the islands. ${ }^{22}$

Nevertheless, the presumed receptiveness of the Chamorros Chamorro to Christian conversion and Spanish colonisation proved to be little more than a romantic notion and the early idealism of the Jesuit missionaries was quickly shattered. The first violent attacks against the Spaniards occurred just six weeks after their arrival and in response to a number Chamorroschamorro dying after being baptised with holy water, which they thought the Spanish were poisoning. In 1669, a missionary was murdered during an evangelising mission through islands north of Saipan. In the same year, soldiers were mustered for the first time to defend Spanish missionaries on the island of Tinian against warring Chamorro factions. Throughout the 1670s, low-level conflict was continuous within the island chain and especially on the islands of Saipan and Tinian. Missionaries were murdered on a regular basis - the most famous of which was the murder of Fray Sanvitores, the founder of the mission, in April 1672. On two occasions this low-level violence erupted into full-scale uprisings. In 1671, two thousand Chamorro warriors attacked the Spanish fort in Hagatna, armed with slingshots and flaming spears. The siege was ended by the appearance of a huge typhoon that wiped out almost all of the houses on the island but left the Spanish defences relatively intact. ${ }^{23}$ In September 1676 another major rebellion-war broke out. Seven soldiers were killed in the initial skirmish and the war was said to last for seven months. ${ }^{24}$ The following year, the Spanish received military reinforcements which allowed them to undertake an aggressive offensive against the resisting Chamorros Chamorro, tearing down houses, burning food stores and killing anyone showing any open hostility. By 1680, more than a decade of Chamorro resistance-violence had led the Spanish to adopt increasingly aggressive measures to consolidate their control over the islands. ${ }^{25}$

\footnotetext{
${ }^{20}$ John N. Schumacher, 'Blessed Pedro Calungsod, Martyr: An Historian's comments on the mission in the Marianas,' Philippine Studies, 49: 4, (2001), 455-487. John N. Schumacher, 'Felipe Sonson: SeventeenthCentury Filipino Jesuit: Missionary to the Marianas,' Landas, 9:2 (1995), 266-285.

${ }^{21}$ AGI, Ultramar, Leg. 562.

22 'Jesuit Annual Report for 1682-1683, by Fr. Solorzano,' in History of Micronesia: A Collection of Source Documents, [Hereafter HoM], Vol. 8, edited by Rodrigue Lévesque, (Quebec: Lévesque Publications, 19922002), 25

${ }^{23}$ Rogers, Destiny's Landfall, 49-55. Coello de la Rosa, 'La sangre de los mártires,' 727-741. De Viana, 'The Pampangos in the Mariana Mission,' 2-5. Francis X. Hezel, 'From Conversion to Conquest: The early Spanish mission in the Marianas,' Journal of Pacific History, 17:3, (1982), 115-137. Schumacher, 'Blessed Pedro Calungsod, Martyr,' 455-487.

24 'Letter from Fr. Coomans to Fr. de Pape, dated Agaña 30 May 1679,' HoM, Vol. 7, 51-54.

${ }^{25}$ Rogers, Destiny's Landfall, 62-65.
} 
The increasing scale of Chamorro resistance to Spanish colonisation during the 1670s impelled the rapid expansion of the Guam garrison. While in 1679 there were 40 soldiers stationed in Guam, ${ }^{26}$ by 1680 this number had increased to 130 soldiers from Spain, New Spain and the Philippines. ${ }^{27}$ For the most part, soldiers were recruited in New Spain as part of the yearly levies for the Philippines, and arrived in the Marianas on board the galleons sailing from Acapulco towards Manila. The length of the Pacific voyage and the known dangers associated with serving in the wild and tropical climate of the Philippines proved a consistent disincentive for most career soldiers to enlist voluntarily. Consequently, the Philippine levies were beset with corruption and relied heavily on legal convictism as well as unscrupulous methods of forced conscription. ${ }^{28}$ Thus, a large number of soldiers who arrived in the Marianas were in fact convicts, or forzados. In 1681 Fray Solorzano described the garrison in Guam as 'Spanish in name only and their customs are effeminate, soft and ineffective. ... [They are] rogues who are made up of exiles from New Spain to the Philippines because in that very large Kingdom they did not fit nor could be tolerated anywhere. ${ }^{29}$

In addition to the reliance on convicts from New Spain, the authorities in Manila also sought to supplement their force by recruiting Filipino soldiers, particularly from the province of Pampanga. ${ }^{30}$ The use of indigenous soldiers in the conquest of other indigenous peoples was commonplace throughout the Spanish Pacific during the seventeenth century. One historian has estimated that up to 40,000 indigenous soldiers served in Spanish expeditions of conquest and pacification across the Pacific between 1575 and 1640, at times outnumbering Spanish soldiers five to one. ${ }^{31}$ Contingents of Filipino soldiers were also present in most of the major Philippines presidios. ${ }^{32}$ The Jesuit missionaries in the Marianas were keen to continue this reliance on indigenous Filipino soldiers, since loyal Filipinos were seen to present a good example to the Chamorro population and could act as conduits for the missionaries. Throughout the early 1680s, the Jesuits held out hope that the Governor of the Philippines would comply with a request sent by the King to dispatch 200 Pampangan soldiers to the Marianas; however, these reinforcements were not forthcoming. ${ }^{33}$ Yet, while Filipino recruits were widely considered to be loyal and valiant soldiers, their situation as

${ }^{26}$ AGI, Filipinas, Leg. 82, Núm. 80.

${ }^{27}$ AGI, Ultramar, Leg. 562.

${ }^{28}$ Mawson, 'Unruly Plebeians and the Forzado System,' 693-730.

29 'Letter from Fr. Solorzno to Fr. Francisco de García, 20 May 1681,' in HoM, Vol. 7, 442.

${ }^{30}$ Stephanie Mawson, 'Between Loyalty and Disobedience: The Limits of Spanish Domination in the Seventeenth Century Pacific,' Unpublished MPhil Thesis, University of Sydney (2014), 86-111.

31 José Eugenio Borao Mateo, 'Filipinos in the Spanish Colonial Army during the Dutch Wars (1600-1648),' in More Hispanic than We Admit. Insights in Philippine Cultural History, (Quezon City: Vibal Foundation, 2008), 75. See also, Mawson, 'Between Loyalty and Disobedience,' 86-111

${ }^{32}$ AGI, Filipinas, Leg. 22, Ramo 1, Núm. 1, Fols. 11R-14V. AGI, Filipinas, Leg. 10, Ramo 1, Núm. 6. AGI, Filipinas, Leg. 32, Núm. 30.

${ }^{33}$ AGI, Filipinas, Leg. 82, Núm. 79. AGI, Filipinas, Leg. 331, Libro 7, Fols. 283R-284V. 
colonised subjects of the Spanish Crown could nonetheless be destabilising in the context of indigenous rebellionviolence, as will be seen shortly.

The Marianas mission became a crucible of soldier discontent during the 1680 s. Set at a distance of more than two thousand kilometres from Manila, the Guam presidio suffered from chronic shortages in supplies. Moreover, the royal officials in charge of the presidio were notoriously corrupt and abusive, sowing the seeds of disaffection through exploitation and the hoarding of supplies. Because many of the soldiers serving in Guam were involuntary recruits, these factors combined were enough to promote mutiny. The fledgling Spanish colony in the Marianas was rocked by mutiny seven times in the 1680s, beginning with two shipboard mutinies in 1680 and 1683 that prevented supplies from arriving in Guam from Manila, and ending with a dramatic convict conspiracy in $1690 .{ }^{34}$ The most successful of these events happened in 1688 , when a group of mutineers led by a forzado captain took control of the island of Guam for a period of three months. Yet, the discontent that boiled over in 1688 has its origins in the events surrounding the Chamorro uprising of 1684, when, in the context of an ongoing indigenous campaign of resistance toagainst Spanish colonisation, the actions of the mutinous soldiers placed the project of empire building in serious peril.

\section{Mutiny in the Context of Indigenous RebellionResistance/Violence: Guam, 1684}

In June 1684, the indigenous Chamorroschamorro of the Mariana Islands staged a major uprising against Spanish conquest. Intent on driving out the Jesuit missionaries and the Spanish officials, the resisting ChamorrosChamorro forced the entire Spanish population on the main island of Guam to barricade themselves in the fort at Hagatna. While some ChamorrosChamorro fought as allies of the Spanish, the garrison and mission were surrounded by a sufficient number of resisting ChamorrosChamorro to remain besieged in the fort for nearly six months. The uprising was centred on the island of Guam and took place within the context of ongoing attempts to spread Spanish control northwards to the other islands in the archipelago. The immediate consequence of the uprising was the complete removal of Spanish forces from the northern islands, the decimation of

\footnotetext{
${ }^{34}$ AGI, Filipinas, Leg. 44, Núm. 34. MARC, RAH, Cortes 567, Leg. 11, 2677, Vol. 2: 'Informe enviado a S.M. referente a las Islas Marianas.' 'Jesuit Annual Report for 1684-1685, by Fr. Gerard Bouwens, dated 30/31 May 1685,' in HoM, Vol. 8, p. 353. 'Official Report from the Governor of the Marianas for the year 1684-1685,' in HoM, Vol. 8, p. 377. 'Letter from Fr. Bustillo to the Duchess, dated Umatac 30 May 1686,' in HoM, Vol. 8, pp. 563-565. MARC, RAH, Cortes 567, Leg. 11, 2677 Vol. 3: 'Carta del P. Lorenzo Bustillo, SJ al P. Antonio Xaramillo, S.J., Proc. Gen. de Filipinas y Marianas. S. Ignacio de Agadña de San Juan de Guan, una de las Marianas.' 'The soldiers' mutiny of 1688, as narrated by Fr. Bustillo,' in HoM, Vol. 9, p. 228. MARC, RAH, Cortes 567, Leg. 12, Doc. 4: 'Estado de las Marianas en la Milicia por Diego de Zarzossa y Lorenzo Bustillo, S.J.'
} 
the Spanish garrison in Guam itself, and the flight of more than two-thirds of the indigenous population of Guam to neighbouring islands not under Spanish control. ${ }^{35}$ The uprising also impelled the authorities in the Philippines and Spain to bolster the military power of the Marianas outpost, allowing the Spanish to completely crush the Chamorro resistance a decade later. ${ }^{36}$

The 1684 Chamorro uprising has thus been remembered as a turning point in the history of Spanish colonisation in the archipelago. In the words of one recent historian, it was the outcome of an 'intense campaign of pacification, conversion and extermination' in Guam. ${ }^{37}$ Yet, the records of the event also tell a story of military leaders who struggled to maintain the loyalty of their soldiers while under siege by thousands of hostile Chamorroschamorro. The seventy-five soldiers inside the Hagatna fort knew only too well how weak their defences were. ${ }^{38}$ Moreover, Governor Esplana, their

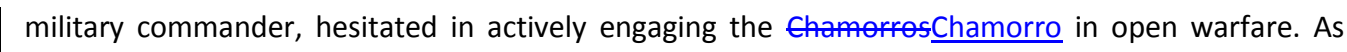
they sat and languished inside the fort for six long months, many of the soldiers found their loyalty to the colonial project failing. Some spoke of outright mutiny, while others discovered that they held greater solidarity with the besieging Chamorroshamorro than with their own leadership. Ultimately, there is another side to the known history of the 1684 uprising, which highlights the limitations of Spanish control not only over indigenous populations, but over their own forces.

The uprising of 1684 took place after nearly two decades of ongoing resistance-opposition by Chamorros Chamorro to the Spanish presence in their islands. The rebels-warriors chose a moment when the Spanish garrison in Guam was depleted due to an expeditionary force that had been sent to try to pacify the northern islands. Thus in June of that year, forty Chamorros Chamorro on the island of Guam rose up and-attacked the main Spanish town of Hagatna, with the intention of killing the governor, the Jesuit friars and any other Spaniard who got in their way. ${ }^{39}$ The initial instigators of

\footnotetext{
${ }^{35}$ AGI, Filipinas, Leg. 3, Núm. 170. MARC, RAH, Jesuita, Tomo 57, No. 43: 'Año de 1684: Carta dirigida al P. Francisco Garcia S.J. por un Padre de la Misión de Marianas.' MARC, RAH, Jesuita, Tomo 207, 9/3779: 'Relación de los sucesos de las Misiones Marianas desde 25 de Abril de 84 hasta primeros de Mayo de 1685.' MARC, RAH, Cortes 567, Leg. 11, 2677, Vol. 2: 'Relación de lo sucedido a las Islas Marianas el año pasado de $1684 . '$ 'Jesuit Annual Report for 1684-1685, by Fr. Cuculino,' HoM, Vol. 8, 229-254. 'Account of events in the Mariana Islands from June 1684 to May 1 1685,' translated by W.C. Repetti, S.J., Guam Recorder, 18, (1941), 98-100, 118-121, 124-126, 159-161. AGI, Filipinas, Leg. 13, Ramo 1, Núm. 9.

${ }^{36} \mathrm{RAH}$, Cortes 567, Leg. 12: 'Relación de la conquista y restauración de las Islas Marianas.' RAH, Cortes 9-2678: 'Carta del Gobernador de Marianas Joseph de Quiroga y Losada ... Isla de San Juan, Mayo 22 de 1696.'

${ }^{37}$ Coello de la Rosa, 'Los soldados de Gedeón,' 20-21.

${ }^{38}$ AGI, Filipinas, Leg. 3, Núm. 170.

${ }^{39}$ This account is based on a summary of the main sources for the uprising: AGI, Filipinas, Leg. 3, Núm. 170. MARC, RAH, Jesuita, Tomo 57, No. 43: 'Carta dirigida al P. Francisco Garcia S.J. por un Padre de la Misión de Marianas.' MARC, RAH, Jesuita, Tomo 207, 9/3779: 'Relación de los sucesos de las Misiones Marianas desde 25 de Abril de 84 hasta primeros de Mayo de 1685.' MARC, RAH, Cortes 567, Leg. 11, 2677, Vol. 2: 'Relación de lo sucedido a las Islas Marianas el año pasado de 1684.' 'Jesuit Annual Report for 1684-1685, by Fr. Cuculino,'
} 
the uprising were four assailants who attacked Governor Esplana in the middle of the street, badly wounding him and leaving him for dead. At the same time, another group went in search of the Jesuits, killing two and wounding four. Later the same afternoon a large group of Chamorroschamorro entered the main church in Hagatna and a stand-off occurred between them and the soldiers who were attempting to defend the Jesuit friar inside. As the rebellion-violence uprising spread across the island of Guam, a Spanish-aligned Chamorro man called Ignacio Ineti raised a force of fifty allies and came to help the garrison defend against the insurgents. Nineteen soldiers were injured during the ensuing skirmishes; however the badly wounded Governor refused to retaliate and instead issued-ordered a retreat back to the safety of the fort. The surviving Spanish forces and the Jesuits were effectively imprisoned within this fort for the next six months, ceding control of the island to the resisting hostile Chamorros Chamorro. After the first bloody battles-at the beginning of the uprising, the rebellion-conflict took on the nature of a war of attrition, wherein the insurgents interchanged between taunting and baiting the besieged Spanish garrison and stealing their crops in an attempt to starve them out of their stronghold.

As the siege continued, every day seemed to bring the beleaguered garrison in Hagatna closer to outright mutiny. The entire Spanish population of Guam - comprising a handful of soldiers and Jesuit missionaries - were beset by Governor Esplana's unwillingness to lead his troops against the attackers. Whether out of resignation, fear or merely because he was badly wounded, Esplana rejected any suggestion made by the increasingly frustrated Jesuits to treat with the Chamorroschamorro. In the meantime, the garrison became restless and disaffected and rumours spread across the camp that a number of the soldiers were thinking of deserting. ${ }^{40}$ Governor Esplana did not help matters by putting the men to work at raising the walls of the fort to strengthen their defences. The Jesuit Fray Bouwens wrote that

The men were worn out with labours that were sensible under the circumstances in constructing and taking apart watchtowers and other tasks, without any more sustenance than a little bit of corn, [and] they lacked the time to cook it for their lunch or dinner: exhausted they would return to work ... with an empty stomach [and labour] from the break of day until twelve and from two until sunset. ... The men were bored by such indispensable labour and they began to mutter, showing

HoM, Vol. 8, pp. 229-254. 'Account of events in the Mariana Islands from June 1684 to May 1 1685,' translated by W.C. Repetti, S.J., 98-100, 118-121, 124-126, 159-161. AGI, Filipinas, Leg. 13, Ramo 1, Núm. 9.

40 'Jesuit Annual Report for 1684-1685, by Fr. Cuculino,' HoM, Vol. 8, p. 249. MARC, RAH, Jesuita, Tomo 57, No. 43: 'Carta dirigida al P. Francisco Garcia S.J. por un Padre de la Misión de Marianas.' 
signs of mutiny: fortunately I and others heard them say clearly that it would be better to finish with them once and for all than to be killed from overwork and hunger. Others threatened to flee to the enemy, assured of finding greater rest and better treatment. ${ }^{41}$

The Jesuits were concerned by this state of affairs, fearing that the desertion of the soldiers or a seemingly inevitable mutiny amongst them would lead to the final collapse of their religious mission in the islands. Fray Bouwens was compelled to write a formal petition to the Governor, entreating him for the sake of the survival of the mission to treat his men better. He begged the Governor to 'please lessen the hours of labour as far as is possible ... and although the work will thus not be carried out so quickly, it will remove the people's just cause for complaint. ${ }^{42}$

Significantly, while the ChamorrosChamorro maintained their desire to purge the island of Spanish domination, their attitude towards the ordinary soldiers was quite different. Throughout the siege, the attackers used a number of different tactics to convince or cajole the soldiers to mutiny and join the resistance, focussing particular attention on the Spanish and Filipino soldiers who had married local women. Mothers of these wives were sent to the gates of the fort with gifts for their sons-inlaw and a message to entreat them to rise up and murder the governor or at the very least desert to the Chamorro camp. ${ }^{43}$ Cleverly, these Chamorro mothers assured the Filipinos that they could trust the Chamorros Chamorro with their lives because 'they had compassion for them since the people of the Philippines had been conquered by Spanish arms. ${ }^{44}$ Eventually five Filipinos deserted and joined the ChamorrosChamorro four months into the siege. ${ }^{45}$ One of these soldiers reportedly sent a letter back to the camp entreating the rest of the Filipino garrison to abandon the fort. He wrote that the Chamorroschamorro were 'making ladders to climb the walls at the hour of prayers or at daybreak and it would be better to leave beforehand. There is no need to distrust the enemy Indios; because

\footnotetext{
${ }^{41}$ MARC, RAH, Jesuita, Tomo 57, No. 43: 'Carta dirigida al P. Francisco Garcia S.J. por un Padre de la Misión de Marianas.'

42 'Fr. Bouwens gives advice to Governor Esplana,' HoM, Vol. 8, 129-130.

${ }^{43}$ AGI, Filipinas, Leg. 3, Núm. 170. 'Jesuit Annual Report for 1684-1685, by Fr. Cuculino,' HoM, Vol. 8, pp. 248249. MARC, RAH, Jesuita, Tomo 57, No. 43: 'Carta dirigida al P. Francisco Garcia S.J. por un Padre de la Misión de Marianas.' MARC, RAH, Jesuita, Tomo 207, 9/3779: 'Relación de los sucesos de las Misiones Marianas desde 25 de Abril de 84 hasta primeros de Mayo de 1685.' MARC, RAH, Cortes 567, Leg. 11, 2677, Vol. 2: 'Relación de lo sucedido a las Islas Marianas el año pasado de 1684.' De Viana, In the Far Islands, 37.

${ }^{44}$ MARC, RAH, Jesuita, Tomo 207, 9/3779: 'Relación de los sucesos de las Misiones Marianas desde 25 de Abril de 84 hasta primeros de Mayo de 1685.' MARC, RAH, Cortes 567 Leg. 11, 2677, Vol. 2: 'Relación de lo sucedido a las Islas Marianas el año pasado de 1684.'

45 'Jesuit Annual Report for 1684-1685, by Fr. Cuculino,' HoM, Vol. 8, p. 249.
} 
all of them in general say that that those who leave the fort will be recognised as children of the land. $^{\prime 46}$

The Jesuits were alarmed by the rumours of impending desertion and mutiny amongst the soldiers, distrusting the Filipinos in particular. Fray Bouwens wrote that the Filipinos were known to be treacherous and that throughout the period of enclosure in the fort they were sowing the seeds of rebellion and discontent amongst the entire garrison. ${ }^{47}$ Fray Kuklein wrote that the Jesuits were so fearful of the internal treachery of these soldiers and their designs on the life of the Governor that they 'undertook to guard [Governor Esplana], telling the soldiers that we wanted to relieve them of the heavy burden of so many watch duties. ${ }^{48}$

The Chamorro siege may well have succeeded had it not been for Sergeant Major Quiroga, who was at that time leading a secondary group of twenty-five Spanish soldiers in a mission of 'pacification' across the northern islands of Saipan and Tinian. This was in fact where most of the fighting occurred. Cut off from the main garrison, Quiroga and his forces found themselves surrounded by resisting chamorro as the uprising acheread across the archipelago. They were consequently forced to quell the uprising in the northern islands before they could return to Guam. ${ }^{49}$ When Quiroga returned to Hagatna in November 1684, news of his exploits on the islands of Saipan and Tinian travelled before him, and the insurgents on Guam melted away before his forces, leaving the town of Hagatna in the hands of the Spanish once again. Nevertheless, many of the Chamorros Chamorro continued their resistance by deserting the island of Guam and refusing to live under the Spanish yoke. ${ }^{50}$ In effect, despite proud reports of Quiroga's successes in quelling the uprising in the northern islands, the Spanish lost control of the rest of the archipelago and remained in reduced numbers in Guam for the next decade until Quiroga launched another expedition to pacify and reduce the populations of the northern islands in $1695 .^{51}$

\footnotetext{
${ }^{46}$ MARC, RAH, Jesuita, Tomo 57, No. 43: 'Carta dirigida al P. Francisco Garcia S.J. por un Padre de la Misión de Marianas.'

${ }^{47}$ MARC, RAH, Jesuita, Tomo 57, No. 43: 'Carta dirigida al P. Francisco Garcia S.J. por un Padre de la Misión de Marianas.' MARC, RAH, Jesuita, Tomo 207, 9/3779: 'Relación de los sucesos de las Misiones Marianas desde 25 de Abril de 84 hasta primeros de Mayo de 1685.' MARC, RAH, Cortes 567, Leg. 11, 2677, Vol. 2: 'Relación de lo sucedido a las Islas Marianas el año pasado de 1684.'

48 'Jesuit Annual Report for 1684-1685, by Fr. Cuculino,' HoM, Vol. 8, pp. 249-250.

${ }^{49} \mathrm{AGI}$, Filipinas, Leg. 3, Núm. 170.

${ }^{50}$ Ibid.

${ }^{51}$ MARC, RAH, Cortes 9-2678: 'Carta del Gobernador de Marianas Joseph de Quiroga y Losada ... Isla de San Juan, Mayo 22 de 1696.' MARC, RAH, Cortes 567, Leg. 12: 'Relación de la conquista y restauración de las Islas Marianas.'
} 
At the same time, although Quiroga's successful entrance into Hagatna in 1684 put an end to the immediate cause for discontent and disloyalty amongst the soldiers, the events of the 1684 uprising had a resounding impact on the garrison. The soldiers' experiences during the siege - of exploitation by their military commanders and of being offered the hand of friendship by those who were supposedly their enemies - were defining. Thus, even though the fear of being overcome by resisting ChamorrosChamorro was removed, the disloyalty of the soldiers continued to cripple the mission. Some of the reasons behind this situation can be located in the endemic corruption and exploitation demonstrated by the governing class of the Marianas. The isolated nature of the outpost meant that Governors of Guam could get away with a lot more than their counterparts in more centrally located presidios. Soldiers stationed in Guam were regularly forced to go without even the most basic of necessities, as a result of corrupt practices by governors such as Esplana. Such behaviour solidified the resolve of the garrison to overthrow their military leadership, which they finally achieved in May, 1688.

\section{The Soldiers' Mutiny of 1688}

By 1688 , the Spanish mission in the Marianas had not received any aid from either Manila or Acapulco for three years, leading to severe shortages and a lack of coin to pay the soldiers' wages. ${ }^{52}$ In response, Governor Don Damian de Esplana decided to set sail for Manila in February 1688 to petition for aid for the colony. On his arrival in Manila, he was immediately detained for having abandoned his post without permission and a lengthy trial was initiated against him. He was later acquitted, but while these events were occurring in Manila, trouble was brewing in Guam. ${ }^{53}$ On 27 May 1688, the soldiers stationed in the Marianas mutinied and seized control of the fort in Hagatna. The leader of this mutiny was a Mexican born convict named Manuel Salgado. ${ }^{54}$ Implicated in a previous plot to mutiny, Salgado had spent the last nine months under the protection of the church, where he claimed asylum from the law. ${ }^{55}$ When discontent broke out within the garrison in May 1688 , Salgado re-emerged from his refuge to take control and lead the mutineers to the house of the interim Governor Don José de Quiroga, which they sacked, pillaged and tore down. The

\footnotetext{
${ }^{52}$ AGI, Filipinas, Leg. 13, Ramo 1, Núm. 9.

${ }^{53}$ Ibid. Driver, 'Cross, Sword and Silver,' 34-35.

${ }^{54}$ MARC, RAH, Cortes 567, Leg. 11, 2677, Vol. 3: 'Carta del P. Lorenzo Bustillo, SJ al P. Antonio Xaramillo, S.J., Dic. 1, 1688.' MARC, RAH, Cortes 567, Leg. 11, 2677, Vol. 3: 'Carta del P. Thomas Cardeñoso al Padre Antonio Xaramillo, S.J., Junio de 1688.' MARC, RAH, Cortes 567, Leg. 11, 2677, Vol. 3: 'Carta del Padre Lorenzo Bustillo a P. Antonio Xaramillo, S.J., Nov. 20 de 1688.' MARC, RAH, Cortes 567, Leg. 11, 2677: 'Carta del P. Gerardo Bouvens al P. Antonio Xaramillo, S.J. Agadña, Mayo 12 de 1689.' MARC, RAH, Cortes 567, Leg. 11, 2677 Vol. 3 : 'Noticias del alzamiento que se ejecuto en Marianas.'

${ }_{55}^{5}$ MARC, RAH, Cortes 567, Leg. 11, 2677, Vol. 3: 'Carta del P. Lorenzo Bustillo, SJ al P. Antonio Xaramillo, S.J., Dic. 1, 1688.'
} 
mutineers then adorned themselves in the Governor's military regalia and paraded around the town in a sign of strength and defiance. Governor Quiroga, who had fled to the Church for protection, was tracked down, seized and placed in shackles inside the fort. ${ }^{56}$ With the capture of the Governor, the Pacific outpost of Guam was effectively under the command of the mutineers and their convict captain for the next three months.

Most of the accounts of the mutiny - written by Jesuits caught up in the events as well as viceregal officials who later reported the events to the King - emphasised the leadership role played by the convict Salgado. As a forzado sentenced to serve in the Philippines, Salgado was representative of the most disloyal and unreliable elements amongst the Spanish military presence in the Pacific. Salgado was described by the Jesuits as 'arrogant, impatient, very restless, a gossip, spiteful, rowdy and always inclined to do wrong. ${ }^{57}$ He had been exiled to the Marianas in 1685 by the captain who was then transporting him from Mexico to serve in the galleys in the Philippines. His example was later used by the Jesuits to argue against the ongoing transportation of convicts to the Marianas. ${ }^{58}$ Yet, at the same time, the focus of the Jesuit sources on Salgado as an inherently criminal and disobedient figure who corrupted the rest of the garrison effectively obscures an examination of the soldiers' motivations to rebel. As a convict, Salgado was presumed to bring with him a natural disobedience and disrespect for viceregal authority. Yet, as we have already seen, the mutinous nature of the garrison in Guam extended beyond the individual figure of Salgado, who arrived in the islands only after the events surrounding the uprising of 1684 . We have already considered the context of ongoing indigenous resistance to the Spanish presence in the Marianas, which directly threatened the lives of the soldiers while also highlighting the disjunction between the interests of the ordinary soldiers and their religious and military leaders. What remains to be considered is the broader context of intense isolation experienced by the Spanish stationed in the Marianas mission, which opened up a space for corruption and exploitation of the soldiers and compelled them towards acts of desertion and disobedience.

Like their counterparts in the Philippines, the Marianas mission was reliant on the arrival of external shipments of aid. Yet, separated from Manila by a distance of more than 2,500 kilometres, the Mariana presidio suffered from an extreme isolation from other Spanish outposts unmatched anywhere else in the Spanish Pacific. The mission ordinarily received supplies from passing galleons en route to Manila, yet the galleons were frequently disrupted by contrary winds, shipwrecks and

\footnotetext{
${ }^{56} \mathrm{lbid}$.

57 lbid.

${ }^{58}$ AGI, México, Leg. 58, Ramo 1, Núm. 10.
} 
the simple absence of available ships. Throughout the early 1680s, the Jesuit missionaries proposed sending regular consignments of aid directly from Manila to the Marianas as a way of making the colony more viable and more appealing to soldiers and prospective colonists. Even with the support of the Governor in Manila, this proposal was difficult to achieve for a number of reasons, including the perceived dangers of the crossing - which was frequently beset by typhoons - and a lack of pilots and sailors willing to make the voyage. ${ }^{59}$ When the supply route between Manila and Guam was finally opened, the first several voyages were disrupted by mutinies amongst the crews. ${ }^{60}$

Consequently, supplies to the mission were limited by unreliable aid shipments and soldiers suffered from a lack of pay, clothing and other basic necessities. Hezel and Driver have noted that many of the early Governors of Guam, including Esplana, exploited this situation to their advantage. Governors turned the supply of provisions designated for the sustenance of the military into a commercial trade, directly controlling the storehouse, where all of the supplies were kept. The soldiers were therefore forced to purchase all of their supplies from the governor, who in turn set the prices. One report indicated that some of the imported goods were overpriced by up to five hundred percent. In this manner, the governors were able to pocket virtually the entire wages of the garrison. ${ }^{61}$ The flight of nearly two-thirds of the Chamorro population of Guam in the wake of the 1684 rebellion waruprising was also a source of increased exploitation of the garrison, who were forced to take on extra work in the fields on top of their military duties in order to feed the Spanish missionary population. ${ }^{62}$ In 1687 , the soldiers of Guam were described as virtually 'ragged and starving' because of Esplana's ineptitude. ${ }^{63}$ One Jesuit commented that the soldiers were overheard to complain that serving in the Marianas was akin to slavery and 'worse than Barbary'. ${ }^{64}$

Some soldiers responded to this situation by taking any opportunity they had to desert. In 1685 , two Filipino soldiers willingly joined the crew of a passing English pirate ship. ${ }^{65}$ The most daring desertion attempt occurred in 1681, however, when two Spanish and three Filipino soldiers stole a boat and

\footnotetext{
${ }^{59}$ AGI, Filipinas, Leg. 11, Ramo 1, Núm. 6.

${ }^{60}$ AGI, Filipinas, Leg. 44, Núm. 34. MARC, RAH, Cortes 567, Leg. 11, 2677, Vol. 2: 'Informe enviado a S.M. referente a las Islas Marianas. Manila 29 de Junio de 1684.'

${ }^{61}$ Hezel and Driver, 'From Conquest to Colonisation,' 144-145. Brunal-Perry, 'Las islas Marianas enclave estratégico,' 551-552.

62 MARC, RAH, Cortes 567, Leg. 11, 2677, Vol. 3: 'Carta del Padre Lorenzo Bustillo al Padre Antonio Xaramillo, S.J. 25 de Diciembre de 1688.'

63 'Letter from Fr. Bustillo to Fr. García dated Guam 10 June 1687,' HoM, Vol. 9, p. 55.

${ }^{64}$ MARC, RAH, Cortes 567, Leg. 11, 2677, Vol. 3: 'Carta del P. Lorenzo Bustillo, SJ al P. Antonio Xaramillo, S.J., Dic. 1, 1688.'

${ }^{65}$ AGI, Filipinas, Leg. 13, Ramo 1, Núm. 9.
} 
set sail for Manila, washing up on the shores of Luzon some weeks later. ${ }^{66}$ Nevertheless, the remoteness of the Marianas archipelago made desertion both difficult and risky, prompting soldiers to turn to mutiny. In 1685 , a soldier died from starvation and exhaustion while labouring in the fields, sparking a short-lived rebellion amongst fifteen of his comrades. This event acted as a direct precedent to the mutiny of 1688, yet Esplana proved incapable of heeding the warning. The Jesuit friars attempted to intervene on behalf of the soldiers and represent their interests to the Governor. The Governor listened to the friars 'without uttering a word, swallowing hard for a few moments, and then ... [he declared] that he was too much of a man to fear, and that no-one would dare to touch him, for he would have anyone who attempted to harm him promptly garrotted ... [and] that he would continue to treat - or ill treat - the soldiers as they deserved both by deed and word. ${ }^{, 67}$ Promptly, the Governor arrested four men without conducting a genuine investigation. He placed them in a dungeon with handcuffs, and the rest of the soldiers quietened down. A month later, some of the men were released because it was found that they had nothing to do with the mutiny.

Corruption and exploitation were not limited to Esplana, even though he was a figure reviled by soldiers and Jesuits alike. When Governor Esplana abandoned his post in February 1688, the Jesuits hoped that his absence would help to calm some of the problems confronting the colony ${ }^{68}$ In reality, however, the appointment of Sergeant Major Quiroga as interim governor while Esplana was away only fuelled the flames of mutiny amongst the soldiers. Don José de Quiroga was invariably known as an excessively pious yet brutal commander with a penchant for imposing harsh military discipline. ${ }^{69}$ Fr. Solorzano described Quiroga as a man of 'very good habits and known virtue' who was nonetheless 'hard of judgment and very self-conceited about himself and his things; he is always full of praises for himself and his nobility. ${ }^{, 70}$ Solorzano believed that Quiroga over-inflated his own position, as if he were the Governor of the Philippines or Flanders, and that he believed himself to be incapable of making mistakes, and so refused to take council from either his own officers or the friars.

As sergeant major and then interim governor, Quiroga thus added the imposition of brutal and harsh command to the soldiers' experience of life in the Marianas. When Quiroga took over as governor in February 1688 , the soldiers were angered when he continued the excessive labour regimen that

\footnotetext{
${ }^{66}$ AGI, Ultramar, Leg. 562. MARC, RAH, Cortes 567, Leg. 11, 2677, Vol. 2: 'Gazeta desde el Junio pasado de 80 hasta el presente de 1681.'

67 'Letter from Fr. Bustillo to the Duchess, dated Umatac 30 May 1686,' HoM, Vol. 8, 584-585.

68 'Letter from Fr. Bouwens to Fr. Mansilla, dated Guam 20 May 1687,' HoM, Vol. 9, 21.

${ }^{69}$ Driver, 'Cross, Sword and Silver,' 30.

70 'Letter from Fr. Solorzano to Francisco García, dated Guam 20 May 1681,' HoM, Vol. 7, 446-447.
} 
Esplana had implemented. Yet by this time, the soldiers already had a litany of grievances against him. In 1681, Quiroga was said to have executed two soldiers for committing the sin of sodomy. He was also instrumental in executing many of the Chamorroschamorro involved in the rebellions-wars of the $1670 s^{71}$ During the 1684 rebellionwaruprising, Quiroga instilled loyalty through exemplary punishment. Surrounded on all sides by hostile and resisting ChamorrosChamorro, Quiroga noticed the faltering resolve of his troops and decided to execute one of them with all the attendant military fanfare. This soldier was accused of having plotted to murder the previous Governor and of disobeying military discipline, and so he was shot. At the conclusion of this affair, Quiroga warned his men, 'God has brought us here to defend His faith and spill our blood in testimony to it, if necessary. ... This assumes that all should abide by the orders of the military and to refrain from offending God, because I cannot but punish with death those that deserve it. ${ }^{72}$

By 1688, Bustillo wrote that the soldiers 'were upset with Don Joseph de Quiroga ... [because of] his style of governing with such supreme haughtiness and severity and under harsh and barren conditions. $^{73}$ The leader of the mutiny, Salgado, had in fact made an earlier attempt at mutiny against Quiroga while he was commander of the Hagatna fort nine months earlier, which had led Salgado to flee into the sanctuary of the church. All of these grievances boiled over into mutiny in May 1688 and Quiroga found himself removed from power and placed in shackles. Significantly, as one of their first acts after seizing power, the mutineers sacked Quiroga's house and emerged adorning adorned with his clothes. This was a powerful symbol of the subversion of power which also highlighted the latent discrepancy between the finery of military leaders like Quiroga and the poverty of the soldiers' meagre provisions. ${ }^{74}$

Horrified by these events, the Jesuits feared that the soldiers' mutiny would spark another uprising amongst the Chamorros Chamorro and end the Spanish mission in the Marianas once and for all. ${ }^{75}$ As the months wore on, however, signs appeared that not all of the soldiers supported Salgado and his decision to imprison Quiroga. In the end, internal splintering amongst the soldiers - encouraged by the Jesuits - broke the mutiny. A rival leader emerged in Captain Nicolás Rodríguez - an ordinary soldier who had been promoted gradually to the rank of Captain through his loyalty to the project of colonisation within the Marianas. Rodríguez became the mouthpiece of the desires of the Jesuit

\footnotetext{
${ }^{71}$ MARC, RAH, Cortes 567, Leg. 11, 2677, Vol. 2: 'Gazeta desde el Junio pasado de 80 hasta el presente de 1681.'

${ }^{72}$ AGI, Filipinas, Leg. 3, Núm. 170.

${ }^{73}$ MARC, RAH, Cortes 567, Leg. 11, 2677, Vol. 3: 'Carta del Padre Lorenzo Bustillo al Padre Antonio Xaramillo, S.J. 25 de Diciembre de 1688.'

74 Ibid.

${ }^{75}$ AGI, México, Leg. 58, Ramo 1, Núm. 10.
} 
friars to restore order to the colony, which they feared would be imminently lost if the sedition of the soldiers was combined with continued indigenous resistance to colonisation. Eventually, behind the backs of the rest of the mutineers, Rodríguez was able to orchestrate the release of Quiroga from his fetters and arrested Salgado and three of his loyal followers. In return, Quiroga issued a general pardon to the rest of the garrison. Despite this, few of the soldiers were happy with this outcome; while Salgado and his three companions were executed on the beach at Hagatna, fourteen of the mutineers were sent back to Manila so that their discontent would be removed entirely from the Marianas. ${ }^{76}$ For his role in the dispute, the once exalted Quiroga completely lost the respect of his company and of the Jesuit missionaries, and his hopes of having his place as Governor of the Marianas made permanent were dashed.

News of the soldiers' mutiny in Guam in 1688 evoked horror from viceregal authorities across the Philippines and New Spain. The events confirmed all of their fears about the potential threat that soldiers' disaffection raised to the viability of imperial expansion in the Pacific. 'That the said government of the Mariana Islands could be in this condition,' Viceroy Conde de Galve noted, 'with an individual of the quality referred, who introduced an entourage of those that, through fear or necessity, followed him,' was warning enough of the precarious nature of colonial projects such as the one in the Marianas. ${ }^{77}$ Salgado's status as a forzado was particularly noted and observers as far away as Mexico suggested that the only solution to avoiding future occurrences of mutiny in the Pacific was to discontinue the use of forzados in the fragile frontier environment. ${ }^{78}$ By comparison, the Jesuit missionaries who witnessed and lived through the mutiny were much more circumspect. None of their accounts of the mutiny explicitly blamed the soldiers for their actions, with the exception of Salgado who is depicted as an unbalanced tyrant. Rather, the Jesuits gave a great deal of credit to the legitimacy of the causes behind the mutiny and laid the blame at the feet of Quiroga and Esplana. In the wake of the mutiny, Fray Juan Tilpe wrote of Quiroga that 'through the supreme power that he had, everything was exposed to danger, and I hope that he will not endanger us anymore, because the lesson will be for nothing. ${ }^{79}$

Fray Tilpe's words were prescient, for this was not the last time that the community in Guam would feel the shocks of discontent amongst the soldiery. Barely two years later, the next wave of mutiny

\footnotetext{
${ }^{76}$ MARC, RAH, Cortes 567, Leg. 11, 2677, Vol. 3: 'Carta del P. Lorenzo Bustillo, SJ al P. Antonio Xaramillo, S.J., Dic. 1, 1688.' MARC, RAH, Cortes 567, Leg. 11, 2677, Vol. 3: 'Noticias del alzamiento que se ejecuto en Marianas.'

${ }_{77}^{77}$ AGI, México, Leg. 58, Ramo 1, Núm. 10.

${ }^{78}$ Ibid.

${ }^{79}$ MARC, RAH, Cortes 567, Leg. 11, 2677, Vol. 3: 'Carta del P. Juan Tilpe, S.J. al P. Proc. Gen. Antonio Xaramillo, S.J. Agat, Enero 28, 1689.'
} 
placed the mission on the brink of complete ruin. In June 1690, a group of forty or more convicts were rescued from a shipwreck just off the coast of Guam. ${ }^{80}$ Delighted by the sudden increase in soldiers, both the Jesuits and the Governor began to talk about the real possibility of using their newly found strength to conquer the northern island of Saipan. Alarmed at the thought of being sent into a violent war of conquest against notoriously hostile natives, the shipwrecked convicts hatched a mutinous plan to kill the Governor and the other officials on the island, as well as the missionaries and any of the other soldiers who got in their way. They resolved to wait until the supply ship was due to arrive from Manila, which they would then board and seize, killing all of the officers and setting sail for Peru. ${ }^{81}$ While this plot was said to originate amongst the forty convicts, the conspiracy finally involved a total of eighty soldiers, and it is unclear from the accounts whether any of these included the soldiers implicated in the previous mutiny of $1688 .^{82}$ Fortunately for the officers and religious friars, the supply ship from Manila was delayed by contrary winds, which kept the ship tacking backwards and forwards off the coast of the islands for three weeks. During this period, some of the conspirators faltered in their resolve, particularly in relation to the plan to kill the friars. Eventually, a pair of soldiers confessed the entire plot to a priest, who promptly informed the Governor. Very quickly, the Sergeant Major of the fort surrounded the convicts in the middle of the night and arrested them at sword point. Over three days in September, twenty three of the would-be mutineers were executed. The rest of the convicts were kept in irons and later sent to Manila on board the supply ship, bringing to a close nearly a decade of mutiny in the Spanish presidio on Guam. ${ }^{83}$

The mutinies on the island of Guam in the 1680s illustrate how soldiers engaged in the colonisation of a new territory could reach breaking point, precipitating a crisis that put at risk the continuation of Spanish control over the Marianas. The soldiers of Guam were confronted by fierce resistance from the indigenous population to the Spanish military presence in the islands. At the same time, many of the soldiers married into the community, and their adherence to the Spanish empire where it existed at all - was challenged by the need to defend the Spanish presence militarily against those who had become their wives, in-laws, neighbours and friends. Their own material conditions were characterised by deprivation, due to the infrequency and insufficiency of supplies from Manila

\footnotetext{
${ }^{80}$ MARC, RAH, Cortes 567, Leg. 12, Doc 4: 'Años de 1689-1691: Estado de las Marianas en la Milicia por Diego de Zarzossa y Lorenzo Bustillo, S.J.'

81 Ibid.

${ }^{82}$ AGI, Ultramar, Leg. 562

${ }^{83}$ Ibid. 'Gerard Bouwens, Letter to Fr. de Pape 24 May 1691,' HoM, Vol. 9, 520-521.
} 
and Mexico, and exploitation rendered by cruel and corrupt officials. Finally, many of them had arrived in Guam against their will as convicts sentenced to military servitude, and their loyalty to the imperial cause was questionable at best.

Mutiny represents the extreme end of the spectrum of the generalised experience of disaffection amongst soldiers in Spain's Pacific presidios. While the story of the soldiers' mutinies in Guam is perhaps exceptional for what it illuminates about the experience of soldiers over a relatively short period of time, these experiences themselves were not exceptional and were felt by soldiers stationed across all of Spain's Pacific presidios. A lack of guaranteed loyalty amongst ordinary soldiers meant that Spanish authorities had to limit their plans for expanding territorial control. The events in Guam in the 1680s also demonstrate that soldiers could be uncomfortable with their role as conquistadors - whether because of the excessive danger of the project of colonisation, or because they found that their interests more readily aligned with those they were conquering than with their military commanders. Moreover, the behaviour of ChamorrosChamorro towards soldiers during the 1684 rebellion-war-uprising shows that the conquistador-conquered dichotomy was not always straightforward. Stories such as these challenge our understanding of the process of conquest and imperial expansion and force us to confront some of our most prevalent assumptions about who engaged in empire construction and who resisted it.

Mutiny and rebellion amongst the soldiers of the Pacific - whether threatened or enacted - thus limited and mediated Spanish domination in the Pacific. Similar interrogations of the agents of empire in other historical contexts has led to deeper understandings of the nature of and processes behind colonial domination as well as a more nuanced picture of the people involved in these processes. ${ }^{84}$ For example, Emma Christopher's examination of sailors on board the ships carrying slaves across the Atlantic in the eighteenth century revealed that even those who were directly involved in the subjugation of some of history's most oppressed subjects could themselves experience degrees of unfreedom and oppression. Furthermore, these sailors were engaged in their own struggle for liberty. ${ }^{85}$ Studies of this nature in turn help to demonstrate that indigenous people were not the only subjects of empire and that resistance to empire could cross constructed racial

\footnotetext{
${ }^{84}$ Burbank and Cooper, Empires in World History, p. 12

${ }^{85}$ Emma Christopher, Slave Ship Sailors and their Captive Cargoes, 1730-1807, (Cambridge: Cambridge University Press, 2006).
} 
boundaries. ${ }^{86}$ Just as indigenous people could be more than victims, Europeans could be more than mere oppressors.

${ }^{86}$ Peter Linebaugh and Marcus Rediker, The Many-Headed Hydra: Sailors, Slaves, Commoners and the Hidden History of the Revolutionary Atlantic, (Boston: Beacon Press, 2000). 